\title{
Partial Acquisition: The Overlooked Entry Mode
}

\author{
Kristian JAKOBSEN* and Klaus E. MEYER** \\ * PhD student Kristian Jakobsen, Department of International Economics and Management, Copenhagen Business School Porcelaenshaven 24, 2000 \\ Frederiksberg, Denmark, kj.int@cbs.dk, www.cbs.dk/staff/Kristian_Jakobsen
}

** Professor Klaus E. Meyer, Department of Management, University of Reading Business School, Whiteknights, Box 218, Reading, Berkshire RG6 6AA, k.meyer@rdg.ac.uk, www.klausmeyer.co.uk

Final draft for a book chapter in:

John Dunning and Phillippe Gugler, eds.

Recent advances in international business research

Elsevier Science

This version May 3, 2007

\begin{abstract}
In certain locations, foreign investors frequently use partial acquisitions (PAs) to access locational advantages controlled by local firms. This chapter aims to explain the use of PAs as a mode of entry in emerging economies, based on two unique samples of foreign direct investments in transition economies and a review of recent entry mode literature. Theoretical considerations and empirical data show that PAs are insufficiently explained by combining arguments for acquisitions (viz Greenfield) and for joint ventures (viz wholly-owned subsidiary). We thus challenge some of the assumptions and assertions of recent entry mode research. In particular, reverse asymmetric information effect may override buyers' informational disadvantages. Thus, PAs are often desired by sellers to attain a share in the expected increase of the firm's value.
\end{abstract}

JEL classification: F21, F23, L22 


\section{Introduction}

Multinational enterprises engaging in foreign direct investment (FDI) combine their ownership advantages with locational advantages of the host country (Dunning, 1992). They can access such locational advantages through different modes of entry. Research on entry modes mostly takes a theory driven approach distinguishing modes either by ownership or based on the 'build or buy' decision (Meyer, 2001; Luo, 2002; Brouthers \& Hennart, 2007). This approach, however, disguises the richness of entry modes as a means to combine ownership and locational advantages. Many firms enter by partial acquisition (PA), especially in transition economies. These PAs combine elements of joint ventures (JVs), namely shared ownership, and of acquisitions, namely taking over an existing operation. Yet, they also have unique features that have been overlooked by prior research. The understanding of PAs is also important to government policy makers as they are the seller side of a privatization by 'partial divestment'.

PAs are a form of acquisition as the investor acquires an equity stake in existing organization, yet without obtaining full equity ownership. Hence, the investors lack full control over the strategy of the business and thus have limited power to effect organizational change. PAs occur in many different facets - in some cases the investor takes over management control and engages directly in the strategic management of the firm, in other cases the acquirer acts more like a financial investor or venture capitalist, advising and possibly indirectly influencing the management, but not taking over direct control.

What all PAs have in common are two defining characteristics: (1) an existing organization, and (2) shared ownership among one or more owners. This definition suggests that a combination of the theoretical literatures on respectively joint-versus-wholly-owned and acquisition-versusgreenfield may provide an appropriate explanation of the phenomenon. However, this does not hold true, as we will argue and demonstrate with empirical data in this paper. 
We review PAs in the context of other modes of entry or expansion, and outline their unique characteristics. We present empirical evidence from two recent research projects covering seven emerging economies in Central and Eastern Europe (CEE), Asia and Africa (Estrin and Meyer, 2004; Meyer and Estrin, 2007) to investigate when and where foreign entrants use PAs. We find

them to be fairly common across a wide range of emerging economies, despite the disadvantages of having operational responsibilities for an existing firm without carrying full equity control. We then proceed to discussing the reasons why both buyers and sellers may prefer a partial acquisition over other modes, despite these disadvantages. We conclude by outlining future research agendas to investigate not only PAs, but also to address conceptual challenges arising from our discussion for the validity of findings of earlier entry strategy research.

\section{Partial Acquisitions as an Entry Mode}

\section{Defining partial acquisitions}

Foreign direct investment (FDI) is an investment in a company in another country with the aim to influence its business strategies (Dunning, 1992). This definition distinguishes FDI from portfolio investment, where equity stakes are too low to exert substantive control, and from contractual relations that normally do not involve equity participation. We focus on entry modes of foreign direct investors.

Categories of entry modes for foreign direct investors are normally defined by their ownership, and whether a new legal entity is created or an existing entity is being taken over. Hence, a greenfield operation is a wholly owned new venture, while an acquisition is defined as obtaining full ownership control of an existing local firm. A JV is defined as the establishment of a 
new venture owned by one or more foreign owners and one or more local owners, while a PA is defined as the acquisition of a substantive stake in an existing local firm.

We operationalise these definitions as follows: Following common practice, we consider investment in equity stakes below $10 \%$ as portfolio investment (OECD 1996), which we do not consider in our analysis. We draw the boundary between partial and full ownership at $95 \%$ foreign equity stake. These operationalisations are fairly robust in that few FDI projects would shift into other categories if the boundaries change by small increments.

Figure 1 illustrates the features of PA shared with other modes of entry. Like a full acquisition, a PA relies on an existing business organisation with all of the advantages and disadvantages associated with this. Much like a JV, the acquirer, however, does not obtain full claim to the residual proceeds nor does the acquirer hold complete equity control. It is the combination of these primary features that distinguishes the PA from the three other principal modes of entry and helps us define what constitutes a partial acquisition.

\section{Figure 1 approximately here}

\section{Challenges to classifying entries}

The formal definition appears fairly clear, yet case evidence suggests that classifying modes in practice is not as easy. For instance, studies in CEE (Artisien-Maksimenko and Rojec, 2001), China (Tsang, 2003) and Vietnam (Nguyen et al., 2004) show that it is fairly common to transfer state assets into a jointly owned new legal entity. Legally, this is a JV because a new legal entity has been created. However this type of investment de facto involves the partial transfer of ownership rights to an existing organization, hence for strategic purposes it resembles a PA. Following Estrin 
and Meyer (2004) we refer to this type of entry mode as 'JV Type II'; Tsang (2003) uses the term 'acquisition JV'.

Furthermore, many full acquisitions related to a privatization come with significant contractual limitations on what the acquirer is allowed or obliged to do often within a certain time period; a type we refer to as "contractually restrained acquisitions". For example, contracts with privatization agencies often require an investor to commit to employment guarantees or capital investment as a condition for the deal to be approved (De Castro and Uhlenbruck, 1998; Meyer, 2002). In other cases, a government agency may retain a golden share with veto-rights for certain strategic decisions. Thus, contrary to common perceptions, full equity ownership does not always provide full control.

A different obstacle to classifying entries is the instability of the ownership arrangement. Many - but not all - partial acquisitions are from the outset planned to be taken over by the foreign investor within the foreseeable future. In many cases, the foreign investor even attained management control ahead of acquiring majority equity ownership. In these cases, the shared ownership is a temporary phenomenon, called 'staged acquisitions' by Meyer and Tran (2006). Analysts would however find it hard to distinguish temporary and stable PAs at the outset.

\section{Types of owners}

The identity of the local partner varies considerably in partial acquisitions and can have a crucial influence on the operation of the PA. In some cases the partner may be a single entity, e.g. the state or a large industrial group, while in other cases ownership may be dispersed between large numbers of small private owners.

In transition economies in $\mathrm{CEE}$, the PAs are in particular associated with the transfer of state

assets into private hands. A number of different privatization methods have been employed, including direct sale to foreign owners, transfer of ownership to insiders of the firm, or broader 
transfers into public hands (Estrin, 2002). Thus foreign acquirers are confronted with a diversity of ownership constellations across CEE.

If the acquisition occurs directly from the privatization agency or a government ministry, foreign acquirers have to deal directly with a state owner. In other cases, new owners (and thus the 'sellers' of the firm) include managers and/or employees of the firm. Some countries experimented with privatization programs designed to spread ownership of formerly state owned enterprises (SOE) broadly, usually through voucher-based schemes. However, the recipients of the vouchers would often invest them in funds, often indirectly controlled by the state, hence inadvertently transferring control rights back into the states sphere. Potential acquirers may thus be negotiating with state-backed investment funds.

A primary challenge for the acquirer is that these owners pursue different objectives that may conflict with the objectives of the acquirer. Particularly, the state or management/employee owners are likely to pose special challenges for the acquirer. These types of owners are likely to have special interest in the firm and pursue objectives other than solely profit maximisation. This can be at odds with the interest of the foreign owner and complicates both the initial negotiation process and the management of the operation after the investors has assumed its equity stake.

In most of our discussion, we assume that the acquirer is a multinational firm taking a strategic interest in the partially acquired firm. This is however not always the case, as a PA may be undertaken for a number of other reasons. For example, private equity funds acquire equity stakes with the aim of benefiting from increased stock values, while helping management to improve the performance of the firm (or even introducing new management). Since these investors actively influence the firm's strategy and equity stakes typically over $10 \%$, this does not qualify as portfolio investment. However, the dynamics of post-acquisition change are quite different than if the acquirer is an MNE aiming to integrate the acquired unit with its global operations. This form of 
investment is however of lesser importance in emerging economies and does not contribute much to the PAs analyzed in the data presented later in this paper.

\section{Theoretical Perspectives}

The OLI paradigm (Dunning, 1992) proposes three necessary conditions for FDI to take place. It suggests that a foreign investor must hold ownership (O) advantages that can be exploited in the foreign market. Furthermore there must be locational (L) advantages that encourage local production. Finally there should be drivers for internalization (I) that encourages internalization of the control rights in the hand of the foreign investor. It is particularly the acquisition and internalization of these location specific advantages that is essential to understand why firms use PA as an entry mode.

Nonetheless, despite the sheer size of the mode choice literature in general (Hennart \& Brouthers, 2007), we know surprisingly little about the use of PAs. And what little we do know may not be relevant for emerging economies. Why might our current theoretical understanding of partial acquisitions fail to capture the motives behind them in emerging economies?

Transaction cost economists explain the partial internalization in JVs by double market failure (Hennart 1991): The project depends on contributions from two or more partners, yet the markets for these contributions from the parents are subject to market failure, i.e. transaction costs are high. A JV structure can overcome the inherent opportunism problem by making both parties residual claimants and thus aligning their interests. Hence, the method of remunerating the input providers is seen as the main motivation for shared ownership.

Brouthers and Hennart (2007) apply this logic and conclude that JVs and PAs are conceptually the same. This argument may be quite useful to explain newly established JVs, yet we consider it misguided to apply the same reasoning to explain the choice of PAs. What distinguishes 
a PA is that a share of the ownership of all organisational resources of the local firm is transferred to a new owner; hence the market failure appears to be of a different nature than that motivating establishment of a JV.

A small number of studies have considered PAs as a distinct entry mode. Cheng and Hennart (2004) suggest an asymmetric information view: An acquirer facing difficulties in valuating the underlying assets would favour a PA over a full acquisition. This would force the seller to provide the acquirer with a "hostage", something the seller would avoid if the underlying asset is a "lemon". It also ensures that the seller continues to act in the best interest of the business.

In transition economies, the nature and importance of asymmetric information may however be different. Evidence suggests that valuations of state enterprises in CEE widely differed between potential buyers and sellers, which greatly complicated negotiations processes (Ferris et al., 1995; Antal-Mokos, 1998; Meyer, 2002; Tsang and Yip, 2007). On the one hand, the greater institutional distance between the home and host country would increase asymmetric information between the foreign buyer and the local seller.

Hence, the underlying assumption that sellers understand the market value of the assets better than prospective buyers is doubtful at best. In particular, the disparity between the value of assets in their current use compared to their first best use would tend to be much higher, due to the weaknesses of incumbent management and rapidly changing industry structures. The seller's knowledge about the potential value of the assets of the local firm is thus limited. Consequently, in the transition context, the asymmetric information argument may not be applicable in the form proposed by Chen and Hennart (2004).

Another study by Duarte (2004) suggests that in high risk contexts, such as emerging economies, firms may prefer to limit their financial exposure by decreasing their equity commitment and pursue a partial acquisition. However this argument is fragile at best. For one, 
from a transaction cost perspective (Williamson, 1975) higher levels of uncertainty is likely to lead to more frequent and more substantial needs for strategic and operational realignments, with corresponding increases in hold up problems. Hence higher levels of uncertainty should all else being equal lead to a greater drive to internalise, not less. Furthermore, from a financial perspective, it is not clear that retaining local shareholder(s) would reduce the cost of capital. Local owners may attach a smaller risk premium to local assets, yet they also face insufficient diversification opportunities, inefficient capital markets and weak institutional protection.

IB scholars may be too accustomed to view the choice of entry mode from the perspective of the foreign acquirer. This may be misleading in transition economies, where firms are often acquired from the state or from employee owners. Ultimately the host governments decided to change the economic system from central planning to a more market based system. Similarly, employees in employee-owned firms decide if and when to externalize the management rights and the residual claim to that enterprise.

In state or employee owned firms, the owner(s) have a vested interest in maximizing the combined value of both their equity stake and other resources, such as labour, that are tied to the firm. Especially the protection of jobs is often a major concern for sellers in transition economies. The main motive of PAs is thus not to maximize the economic efficiency of the acquired unit by curbing opportunism, but rather to provide protection against harmful (autonomous) adaptation (Hayek, 1945; Williamson, 1975). Thus, the choice of entry mode is not a unilateral decision made by the acquirer but the result of a negotiated process between two or more parties.

\section{Empirical Evidence from Questionnaire Surveys}

Empirical evidence on PAs in a wide range of emerging economies is available from two surveys conducted in emerging economies. The first survey was conducted using a set of countries 
from Asia and Africa, while the second survey was conducted in transition economies in CEE. Together, these surveys represent more than 1000 observations in seven countries: India, Vietnam, Egypt, South Africa, Hungary, Poland and Lithuania. The data collection process has been described in Meyer and Estrin (2004) for the Asian survey and Meyer and Estrin (2007) for the CEE survey. These data illustrate the distinct features of PAs, which international business scholars ought to consider when advancing their theories. All the statistical analyses were conducted using the SPSS software package.

\section{Table 1 approximately here}

\section{Location}

Table 1 indicates a fairly consistent distribution of PAs across all seven countries with investors in India being the least likely to use PAs and those in Poland being the most likely with respectively seven and sixteen percent of all entries. However, these figures may possibly under represent the true importance of PAs because of deal structures that for practical purposes resembles PAs but legally are JVs (Tsang, 2003; Estrin and Meyer, 2004). In the case of Vietnam, no partial acquisitions have been captured by the survey, however a large number of foreign entries followed the 'JV type II' mode which had been listed as a separate option in the Vietnam version of the questionnaire (Nguyen et al., 2004), and which we tabulate here as PA.

In contrast, full acquisitions are rare in Egypt, India and Vietnam compared to the three CEE countries and South Africa. An important reason for this factor is related to legal ownership restrictions in these countries and the liquidity of markets for corporate equity. Hence institutional factors are clearly an important determinant in the entry mode choice as MNEs normally expanding by acquisitions need to find alternative means to access local resources. This suggest that the 
theoretical position of Brouthers and Hennart (2007) to isolate the make or buy viz. full or partial ownership decision is not very helpful to understand the realities of business in emerging economies. Firms need to consider all the available alternatives simultaneously.

More importantly, our evidence establishes PAs as an important entry mode in its own right in emerging economies, especially transition economies. For the remaining empirical analysis, we focus on the CEE data set to ensure that meaningful comparisons can be made to full acquisitions.

\section{Table 2 approximately here}

\section{Subsidiary size}

Table 2 reports the initial mean firm size in terms of number of employees and the natural $\log$ of the number of employees ${ }^{1}$ for different entry modes, along with an ANOVA significance test of the variation (F) and the Eta measure of association. For a relationship between a continuous dependent variable and an independent variable that have a limited number of categories the Eta measure is similar to the correlation coefficient. For each (ANOVA) test the F value and the Eta measure of association is calculate. The $\mathrm{F}$ value is derived using the formula:

$$
F=\frac{S S T /(Z-1)}{S S E /(N-1)}
$$

Where $(\mathrm{Z}-1)$ is the degrees of freedom of the independent variable and $(\mathrm{N}-1)$ is the degrees of freedom for the sample. SST, the total sum of squares is calculated by aggregating the squared difference between $\mathrm{Y}$ and the grand mean $\bar{Y}_{G}$.

$$
S S T=\sum\left(Y-\bar{Y}_{G}\right)^{2}
$$

\footnotetext{
${ }^{1}$ Since the relationship between size and entry mode choice is not expected to be strictly linear and since the type of dependent variable has a long tail the natural log tends to provide more robust results.
} 
SSE, the Sum of squares error is then calculated by aggregating the squared difference between $\mathrm{Y}$ and the treatment mean $\bar{Y}_{\text {mode }}$

$$
S S E=\sum\left(Y-\bar{Y}_{\text {mode }}\right)^{2}
$$

Finally the measure of association is derived by the formula:

$$
\text { Eta }=\sqrt{\frac{(S S T-S S E)}{S S T}}
$$

Due to the limited number of full acquisitions in the Asia-Africa data set (Table 1), we include only the CEE countries. The results suggest that PAs are on average larger than entries by any other mode, including full acquisitions. This suggests that partial acquisitions have a comparatively large economic impact on host countries and account for a substantial share of the employment of foreign owned firms. Understanding the peculiarities of this entry mode should therefore be of great practical concern to both policy makers and business strategists.

This strong association between size and partial acquisition suggests that it may be necessary to control for this influence in some of the subsequent empirical analysis. We thus adopt a stepwise approach estimating the marginal contribution of the entry mode using a methodology adapted from Cantwell and Mudambi (2000). We first regress, using an OLS regression, the dependent variable $\mathrm{Y}$ against the independent variable $\mathrm{X}$ which either takes the values of subsidiary size if the expected relationship is mathematically conditioned or $L N($ subsidiary size) if the expected relationship is conceptually conditioned.

$$
\mathrm{Y}=\mathrm{a}+\beta \mathrm{X}+\mathrm{u}
$$

We then collect the residual denoted by $r$ of this regression and use them as the dependent variable in a one-way analysis of variance (ANOVA) test with the entry mode choice as the independent variable. The key advantage of this technique over a multivariate OLS regression is that this method eliminates any multi-collinearity between subsidiary size and entry mode. 
Furthermore it is hierarchical in the sense that the size effect is controlled for before conducting the ANOVA on the marginal influence of the entry mode choice ${ }^{2}$.

\section{Table 3 approximately here}

\section{Governmental influences}

Table 3 reports the relationship between government influence on a business and entry mode. The variable government influence is measured as a 5 point Likert scale variable; see the Appendix for a description of this variable. The initial values suggest stronger government influences on PAs. However, when correcting for subsidiary size using the two step approach, the overall significance of the relationship disappears. Hence the effect of government influence appears to be largely derived from the size of the enterprise; in other words the political establishment is more likely to interfere the larger the enterprise - but not in PAs per se.

This suggests two important factors that may explain the use of PAs in transition economies: First of all, employment is a major concern for governments in transition economies, as suggested above when discussing types of owners. Moreover, governments have the means and the incentive to indirectly interfere in the operation of firms, regardless of entry mode. Full ownership in it self is thus not necessarily sufficient to guaranty complete managerial control. Consequently, foreign owners may more willingly accept some form of shared ownership if it provides an element of protection against adverse interference by the state (Meyer, 2002).

\section{Table 4 approximately here}

\footnotetext{
${ }^{2}$ Consider the government influence in the next subsection. If we make the plausible case that governance influence is larger in partial acquisitions because they are large then it makes sense to eliminate this proponent first.
} 


\section{Resource transfers}

A common concern about PAs is that investors may be reluctant to transfer resources, especially hard to value and intangible assets, to their new affiliate if they do not control the use of these transferred resources, and have to share any rents thus generated with a local co-owners.

Table 4 reports the relationship between entry mode and the transfer of knowledge to the affiliate. Two proxies for transfers are used, investment in human resource development and the foreign subsidiary's access to resources from the parent company. The human resource measure is a principal component based on three 7-point Likert scale variables (see Appendix). The Cronbach's Alpha test yielded a result of $(0,801)$ indicating a good fit. As larger enterprises are more likely to have formal human resource development programs we account for this by adopting the two step approach regressing the principal component against the $L N($ subsidiary size). The residual is then used as the dependent variable in the ANOVA test.

The second measure is a principal component based on three 7-point Likert scale measures of perceived access to financial, managerial and technological resources from the parent company. The Cronbach's Alpha test yielded a result of $(0,797)$ indicating a good fit.

Both measures were found to be significantly related to entry mode at the 5 percent and 10 percent level respectively. The results show that partial acquisitions are less likely than any other mode to benefit from investment in human capital and also receive comparatively less resources from the foreign investor. This remarkable finding has substantive implications as it suggests that PAs may be at a substantial operational disadvantage compared to other modes. On both items, Greenfield projects seem to receive most support from the foreign parent.

Resources transfers tend to be low in both JVs and PAs, which support the argument that shared ownership would reduce investors' incentives to share knowledge with a new affiliate. Investment in human capital is on average lower in PAs compared to any other mode. This is likely 
to be the consequence of the combination of organisational inertia in an inherited organization and adverse incentives arising from shared ownership.

\section{Table 5 approximately here}

A similar concern arises with respect to foreign investors' willingness to invest in risky organizational change processes if they do not have full control (Meyer and Estrin, 2007). Table 5 reports the relationship between change in employment and entry mode choice, the first is a simple means test reporting the mean change in employment per year ${ }^{3}$ viz. the choice of entry mode. The ANOVA test on the difference of means suggests that PAs would tend to destroy jobs. However, when controlling for the initial size of the operation, using our two step approach, the results change substantially. PAs are no longer associated with employment destruction, but surprisingly show a small though insignificant propensity to create or preserve jobs. Finally we investigate the absolute value of the change in employment across entry modes. The results again do not indicate significant deviation across entry modes when corrected for initial size.

The job destruction in PAs thus arises from the much larger size of PAs at the outset; it is not caused by the choice of PA as an entry mode per se. Many state owned firms in CEE employed before privatisation a substantially larger work force than what was required. A reduction of employment in large enterprises may thus be a necessary part of the restructuring (Estrin, 2002), and PA is chosen as an organizational form to implement this aim.

The propensity of PAs to create or destroy jobs after controlling for size is not significantly different from other modes. If it was true that local co-owners obstruct restructuring that involves lay-offs, we would see a positive coefficient after controlling for size, and a negative coefficient

\footnotetext{
${ }^{3}$ This variables has been defined as [(employment at the time of survey - employment in first year of operations $)$ / age of subsidiary in years].
} 
when considering the absolute value of the change. The coefficients are both positive - but the Fstatistic shows that this effect is clearly not statistically significant.

Thus, the impediments to full control may be offset by countervailing forces. As previously suggested, even in full acquisitions, employees or the government could potentially constrain the operational flexibility of the foreign owned subsidiary indirectly.

Another possibility is that there are some intrinsic advantages of partnering with local stakeholders. A partnership with local stakeholders may provide the subsidiary with a shield against adverse opportunistic activities by other stakeholders. Hence the operational freedom of a partial PA may in fact be comparatively larger. It is also possible that local co-owners may facilitate access to new business licences and permits, real estate etc, therefore contributing to new growth opportunities. Finally an alternative explanation is that co-ownership with employees could encourage smoother redeployment of resources into more productive uses.

\section{Summary}

We find that PAs are fairly commonly used across emerging economies, even in relatively advanced ones such as South Africa. The propensity for PAs varies across countries as for all modes of entry, which suggest that institutional, location and cultural aspects play an important role in the entry mode choice. Furthermore, our data indicate that PAs tend to be larger in terms of employment than other foreign entries. Considering the fairly consistent use across a broad range of transition economies and their comparatively large economic impact on the host countries, PAs clearly merit scholarly attention. Our exploratory analysis of the characteristics of PAs shows distinct features. Some of these features appear to the size differences, while others are not:

- We find indirect evidence of increased government influence in large enterprises pointing to the possibility that firms chose PAs to align the host countries interests with that of the investor or 
as a shield against possible adverse government interference.

- We find lower transfers of resources from the foreign investor and less investments in human resource development in PAs, pointing to a combination of lower incentive to transfer resources and organisational friction or inertia

- We find no evidence to suggest that PAs are organisationally more rigid. Retention rates and overall organisational change is not significantly affected by the limited control, suggesting a series of possible countervailing forces facilitating growth opportunities.

These results should however be treated as preliminary. Even though we control for size of the affiliate, rigorous analysis would call for multivariate techniques. Our exploratory analysis thus mainly services to outline challenges for future research.

\section{Motives: Acquirer's Perspective}

What advantages and disadvantages does a PA offer? Unlike a JV, the advantages derived from a local co-owner is unlikely to be related directly to market knowledge, managerial skills etc. Similar to a full acquisition we may expect these to reside within the acquired organisation. However there may still be a unique set of advantages that makes a partial acquisition an attractive entry mode.

\section{Reduced ex-ante contracting costs}

The process of acquiring a local firm in a transition economy can be a slow and difficult exercise (Artisien-Maksimenko and Rojec, 2001) that runs the risk of being hijacked by various groups of stakeholders (Antal-Mokos, 1998). As suggested above, ownership of assets in transition economies is often in the hands of stakeholders that have other primary interests than profit maximization, most notably protecting jobs. Even when stakeholders are not directly involved in 
the negotiation process they may still successfully exert indirect pressure. Antal-Mokos (1998) and Meyer (2002) provide several examples of ex-ante negotiations that have failed or been drawn out due to intervention by other stakeholders in the process.

It is also common in transition economies that an acquirer contractually commits to undertake a certain level of investment, or, for instance, not to close plants or lay off employees within a certain period. For example, Rieber \& Søn a Norwegian operator in the food retail industry acquired Delecta SA, an employee owned firm in Poland, and contractually obliged not to make changes within a three year period (Dale, 2006). We have no way of segmenting acquisitions that are contractually restricted from acquisitions that are not, however anecdotal evidence suggest that this has been fairly frequent. Consequently the relative level of operational freedom enjoyed by full acquisitions should not be overestimated.

Local ownership participation may ease some of hurdles and thus speed up the negotiation process. For the foreign investor, a partial acquisition may be the fastest way to gain access to a market and secure early mover advantages. Thus, Jakobsen (2006a) finds that early entry through partial acquisition enhances the performance of a new operation. Hence a key advantage of partial acquisitions may be to reduce the ex-ante contracting costs.

\section{Legitimacy}

Retaining a local partner may also enhance the legitimacy of the venture in the host country. Even in developed market economies, public opinion may perceive the acquisition of a local firm by a foreign enterprise with some misgivings (Crystal, 2003). This is particularly important in transition economies where governmental agencies often have indirect means to influence the prosperity of a business. An ownership stake by the state in the local firm is thus a potential mean to align the interests of the foreign partner and the government (Meyer, 2002). Our study suggests that PAs may enjoy certain advantages in gaining access to new growth opportunities on account of 
local ownership participation. Even when the partner is not a state or employee owner, the presence of a local partner may deflect some of the misgivings in the host country.

\section{Increased governance cost}

However, there are also disadvantages associated with joint ownership. Retaining a local partner raises the governance costs of the venture (Luo, 2002). In uncertain environments that require frequent strategic and operational adaptation, the need to negotiate changes with a local partner may significantly affect the enterprise's ability to speedily affect changes consequently increasing the governance cost. This may especially be a problem when the local partner has different objectives which will often be the case with employee or state owners.

\section{Weak incentives}

Moreover, the absence of full ownership and the lower residual claim this implies reduces the attractiveness of finding opportunities for the transfer of resources from the foreign parent to the local subsidiary. In essence the partial acquisition mode lacks the high powered incentives of a wholly owned subsidiary. Evidence from this study suggests that both the transfer of resources from the foreign parent and investments in human resource development may be impaired in PAs.

\section{Motives: Sellers Perspective}

A PA is the outcome of an agreement between an investor and the previous owner(s) of the firm. While the entry modes choice literature has largely focused on investors, it is essential to also understand the seller's perspective to explain why PAs emerge as the mutually agreed outcome.

\section{Retain stakeholder influence}

Possibly the strongest motive for local owners to prefer a partial divestment (a PA seen from the seller's perspective) is the desire to retain some influence in the enterprise. Sellers in transition 
economies often have other stakes in the enterprise apart from their equity stakes. Hence they are naturally reluctant to completely turn over control to an outside owner, even when this is necessitated by the need for external financial, managerial and technological resources.

In order to protect their interests they may turn to contractual provisions. However this type of contracting is likely to be extremely cumbersome in high uncertainty environments, like transition economies, and in organisations that require extensive restructuring. A partial divestment is thus a deal structure that balances the need to protect the interests of the stakeholders while ensuring that ex-ante contracting costs stays within acceptable limits. The evidence in this study does suggest that partial acquisitions are larger in terms of employment, which again would suggest that the mode choice is motivated by labour concerns.

\section{Rent appropriation}

Foreign direct investors are motivated by their desire to exploit their ownership advantages in another country (Dunning 1992). They may enter by acquisition if they are confident that they can create more value from the acquired organization than the previous owners. In competitive markets for corporate governance, we would expect some of this additional value to accrue to the seller through the acquisition premium. However local owners in rapidly changing environments are often poor at pricing their own assets, let alone estimating their potential value in their first best use - a reverse asymmetric information problem (Jakobsen, 2006b). Local owners may therefore prefer to retain a stake in the enterprise to ensure that they get a share of the increased value of the firm.

\section{Incompatible investment time horizons}

There are of course also disadvantages to retaining an ownership stake. Often, foreign investors take a long term investment horizon, and focus on expanding and consolidating their market position, which means the free cash flows generated by the enterprise, will usually be 
reinvested in the business. In contrast, local owners may prefer that some of the free cash flow is released as dividends. They may also risk that the discrepancy in the investment horizon could lead the foreign owner to deliberately depress dividends with the implicit aim of forcing them to sell out.

\section{Governance concerns}

Another potential source of discomfort for a local minority partner is the often poor minority shareholder protection offered in transition economies. While low dividend pay outs may strain the minority partner, the MNC may pursue business practises that are directly harmful to the minority partner. Particularly transfer pricing policies may be a source of contention between the partners.

\section{Conclusions}

\section{Public Policy implications}

Policy makers in governments see partial divestment as a means to privatise state-owned enterprises. This form of attracting FDI, however, has some unique characteristics, and thus impact on the host economy. Contrary to journalistic opinions, PAs are not associated with the destruction of jobs; rather this effect is attributable to the large size of many PAs in transition economies. However, we find that PAs are associated with fewer resource transfers from the investor, and less investment in human capital in particular.

Policy makers may consider PAs useful to soften the economic and social impact of the transfer of ownership in large firms subject to significant structural changes in the industry. However, this softened social impact of necessary economic restructuring may come at the cost of slower efficiency gains and delayed upgrading of the resources and capabilities of the firm. It would thus be ill advised to pursue such a policy indiscriminately; hence general legislation promoting or limiting the choice of entry modes is likely to be economically suboptimal.

\section{Future directions for the study of partial acquisitions}


Our analysis suggests that the existing literature fails to capture essential aspects of PAs. Firstly, we argue that the assertion by Brouthers and Hennart (2007), that the method of remunerating the input providers is the main determinant of both JVs and PAs is insufficient to explain PAs. Secondly, we argue that Chen and Hennart's (2004) asymmetric information view on PAs fails in transition economies because of probably important reverse asymmetric information effects.

We argue that PAs are preferred when the seller wish to protect upstream resources from harmful autonomous adaptation (Williamson, 1975). Consequently the preference for a PA is at least in part motivated by the seller's desire to influence the decisions made by the jointly owned economic unit. Evidence to support this argument was found in relation to the employment in PAs. This argument provides an alternative view to the remuneration of input providers argument (Brouthers and Hennart, 2007), which holds that partial ownership aligns the interests of the owners, hence effectively eroding the scope for self-serving opportunism.

Future research on entry mode choices should therefore take a more nuanced approach. In particular, future studies should recognize that mode choices are rarely unilaterally but rather the outcome of a bilateral negotiation process. Furthermore, the underlying assumptions of many traditional approaches may fail to capture the motives of the entry mode choice in emerging economies. Hence, studies in these economies promises to produce results that may broaden our understanding of the nature and boundaries of the firm.

\section{Challenges for theorizing in international business research}

Our analysis of PAs raises major concerns with respect to the dominant avenues for theory building in international business research, especially with respect to foreign entry modes (cf. Brouthers and Hennart, 2007). In particular, our digging deeper in the character of this particular 
mode reveals that theories often make implicit assumptions about the nature of entry mode that do not represent a close depiction of the real world.

Firstly, the (often implicit) assumption that decisions on ownership and on acquisitionversus-greenfield are independent clearly does not hold. Hence, the assumption that decisions are separate, or at least analytically separable, has to be re-examined. There is little empirical evidence of such a separation. Hence, Figure 1 serves to classify modes, but it is insufficient to build explanatory models on these two dimensions only, as PAs are subject to influences that cannot be explained by combining these two perspectives. Moreover PAs share with both JVs and acquisitions the access to resources held by local firms, albeit under different legal and organizational arrangements. Since the question of whether or not such local resources are needed is a key starting point for planning an FDI project, it is more likely that the initial decision is between Greenfield and modes-providing-resource-access, and in the second stage the appropriate mode is selected for accessing these resources (Meyer, Estrin and Bhaumik, 2005; Jakobsen, 2006b).

Second, the (often implicit) assumption that entry modes are clearly delimitated using the logic of Figure 1 is challenged by the observation from case research (Estrin and Meyer, 2004; Meyer and Tran, 2006; Meyer and Estrin, 2007) that certain projects are in fact hard to classify. Specifically, where are the boundaries between (a) JV and PAs in the case of JV Type II, and (b) partial and full acquisitions in the case of staged acquisitions or contractually restrained acquisitions?

Third, the (often implicit) assumption that mode choice is primarily decided by the investor based on costs and benefits of alternative arrangements does not hold. Rather, PAs are the outcome of a bilateral bargaining process between buyer and seller - and similar bargaining with local partners occurs in the case of JVs (Harrigan, 1988) and acquisitions. 
Fourth, the (often implicit) assumption that initial ownership arrangements are fairly stable clearly does not hold for PAs (Meyer and Tran, 2006), nor does it hold for JVs (Harrigan, 1988; Buechel, 2002). Rather, PAs are often transitory arrangement aimed at full acquisitions in form of staged acquisitions. Future research thus may need to focus more on dynamic processes of entry and the post-entry development, rather than at entry mode as a cross-sectional phenomenon. 


\section{REFERENCES}

Antal-Mokos (1998). Privatisation, Politics, and Economic Performance in Hungary, Cambridge University Press, Cambridge.

Artisien-Maksimenko, P., and Rojec, M. (2001). Foreign Investment and Privatization in Eastern Europe: An Overview, in P. Artisien-Maksimenko and M. Rojec, eds., Foreign investment and privatization in Eastern Europe, Baskingstoke: Palgrave, p. 1-.

Brouthers, K. D., and Hennart, J.-F. (2007). Boundaries of the Firm: Insights from International Entry Mode Research, Journal of Management, Forthcoming

Buechel, B. (2002). Joint venture development: Driving forces towards equilibrium, Journal of World Business 37(3), 199-207.

Cantwell, J., and Mudambi, R. (2000). The location of MNE R\&D activities: The role of investment incentives, Management International Review 40, 127-148.

Chen, S-F., and Hennart, J.-F. (2004). A hostage theory of joint ventures: why do Japanese investors choose partial over full acquisitions to enter the United States? Journal of Business Research 57(10), 1126-1134.

Crystal, J. (2003): Unwanted company: Foreign Investment in American Industries, Ithaca: Cornell University Press.

Dale, K. (2006). Entering into Poland: an examination of how entry mode affects transfer of knowledge and human management resource integration. Unpublished master thesis, Copenhagen Business School, Copenhagen.

Duarte, C. L., and Garcia-Canal, E. (2004). The Choice between Joint Ventures and Acquisitions in Foreign Direct Investments: The Role of Partial Acquisitions and Accrued Experience. International Business Review 46(1), 39-58.

Dunning, J.H. (1992). Multinational Enterprises and the Global Economy, Addison-Wesley: 
Harlow.

Estrin, S. (2002). Competition and Corporate Governance in Transition, Journal of Economic Perspectives 16(1), 101-124.

Estrin, S., and Meyer, K. E. eds. (2004). Investment Strategies in Emerging Markets, Aldershot, UK and Northampton, MA, USA: Edward Elgar.

Ferris, S.P., Yoshi, Y.P., and Makhija, A.K. (1995). Valuing an East European Company, Long Range Planning 28(6), 48-60.

Harrigan, K.R. (1988). Joint ventures and global strategy, Columbia Journal of World Business 14(2), 36-64.

Hayek, F. (1945). The use of knowledge in society. American Economic Review 35, 519-530.

Hennart, J.-F. (1991). The transaction cost theory of the multinational enterprise, in C. N. Pitelis and R. Sudgen editors, The nature of the transnational firm, Routledge.

Jakobsen, K. (2006a). First mover advantages in Central and Eastern Europe: A comparative analysis of performance measures. In J. Larimo and S. Rumpunen, editors, Internationalization and management of foreign operations. University of Vaasa: Vaasa, 365387.

Jakobsen, K. (2006b). The choice of entry mode in transition economies: The role of partial acquisition, European Academy of International Business, conference paper, Oslo: December.

Luo, Y. (2002). Capability exploitation and building in a foreign market: Implications for multinational enterprises. Organization Science 13(1), 48-63.

Meyer, K. E. (2001). International Business Research in Transition Economies, Oxford Handbook of International Business, Oxford: Oxford University Press, 716-759. 
Meyer, K. E. (2002). Management challenges in privatization acquisitions in transition economies. Journal of World Business 37(4), 266-276.

Meyer, K. E., Estrin, S., and Bhaumik, S. (2005). Greenfield versus Cooperative Entry in Emerging Economies: A Resource-based and Institutional Perspective, Working Paper, Centre for New and Emerging Markets, London Business School.

Meyer, K. E. (2007). Contextualising organisational learning: Lyles and Salk in the context of their research, Journal of International Business Studies 38 (1). 27-37.

Meyer, K.E., and Estrin, S. eds. (2007). Acquisition Strategies in European Emerging Economies, Baskingstoke: Palgrave Macmillan.

Meyer, K. E., and Tran, Y. T. T. (2006). Market penetration and acquisition strategies for emerging economies. Long Range Planning, 39(2), 177-197.

Nguyen, HT., Nguyen, VH., and Tran NC. (2004). Vietnamese Case Studies, in S. Estrin and K.E. Meyer (Eds.), Investment Strategies in Emerging Economies, Cheltenham: Elgar.

OECD (1996): OECD Benchmark Definition of Foreign Direct Investment, Paris: OECD. (www.oecd.org/dataoecd/10/16/2090148.pdf, accessed May 2007)

Tsang, E. W. K. (2003). Resistance to restructuring in Sino-foreign joint ventures: Toward a preliminary model, Journal of Organizational Change Management 16, $205-222$.

Tsang, E. W. K., and Yip, P. S. L. (2007). Economic distance and survival of foreign direct investments, Academy of Management Journal, Forthcoming

Uhlenbruck, K., and De Castro, J. (1998). Privatization from the Acquirer's Perspective: A Mergers and Acquisitions Based Framework, Journal of Management Studies 35, p.619-640.

Williamson, O. E. (1975). Markets and hierarchies: Analysis and antitrust implications. Free Press. New York. 
Figure 1: Ownership control and the make or buy decision

\begin{tabular}{c|c|c|}
\multicolumn{1}{c}{} & \multicolumn{1}{c}{$\begin{array}{c}\text { New } \\
\text { organizations }\end{array}$} & $\begin{array}{c}\text { Existing } \\
\text { organizations }\end{array}$ \\
\cline { 2 - 3 } $\begin{array}{c}\text { Full equity } \\
\text { Control }\end{array}$ & Greenfield & Acquisition \\
\cline { 2 - 3 } $\begin{array}{c}\text { Shared equity } \\
\text { Control }\end{array}$ & Joint venture & $\begin{array}{c}\text { Partial } \\
\text { acquisition }\end{array}$ \\
\cline { 2 - 3 } & & \\
\cline { 2 - 3 } & &
\end{tabular}

Table 1 Distribution of affiliates by entry mode ( $\%$ of affiliates)

\begin{tabular}{l|ccccccc}
\hline Entry Mode & Hungary & Lithuania & Poland & Egypt & India & South Africa & Vietnam \\
\hline Greenfield & 43 & 40 & 42 & 46 & 35 & 31 & 56 \\
Joint Venture & 23 & 19 & 20 & 37 & 53 & 23 & 32 \\
Acquisition & 25 & 30 & 21 & 5 & 4 & 31 & 2 \\
Partial Acquisition & $\mathbf{9}$ & $\mathbf{1 1}$ & $\mathbf{1 6}$ & $\mathbf{1 2}$ & $\mathbf{7}$ & $\mathbf{1 4}$ & $\mathbf{1 1}^{\mathbf{1}}$ \\
\hline
\end{tabular}

Notes: Column total $=100+/$ - rounding;

${ }^{1 /}$ Vietnam: Partial acquisitions were defined as JV where local firms transfer part of the existing operation to the newly created JV.

Source: Meyer et al., in Meyer and Estrin (2007).

Table 2 Mean initial size of the local enterprise by entry mode

\begin{tabular}{lcccc}
\hline Entry Mode & \multicolumn{2}{c}{ Subsidiary Size } & \multicolumn{2}{c}{ LN(Subsidiary size) } \\
\hline & Mean & SD & Mean & SD \\
Greenfield & 38,23 & 99,54 & 2,60 & 1,29 \\
Joint Venture & 66,65 & 141,16 & 3,15 & 1,38 \\
Acquisition & 275,11 & 530,65 & 4,37 & 1,68 \\
Partial Acquisition & $\mathbf{2 6 6 5 , 0 2}$ & $\mathbf{6 5 8 9 , 1 5}$ & $\mathbf{5 , 0 7}$ & \multicolumn{2}{c}{$41,92 * * *$} \\
\hline F & \multicolumn{3}{c}{$17,60^{* * *}$} & \multicolumn{2}{c}{0,496} \\
Eta & \multicolumn{2}{c}{0,347} &
\end{tabular}

Notes: Poland, Lithuania and Hungary only, levels of significance: $\mathrm{P}<0.011^{* * *}, \mathrm{P}<0.05^{* *}, \mathrm{P}<0.10^{*}$. 
Table 3 Mean influence of local governments by entry mode

\begin{tabular}{|c|c|c|c|c|}
\hline \multirow[t]{2}{*}{ Entry Mode } & \multicolumn{2}{|c|}{ Government influence } & \multicolumn{2}{|c|}{$\begin{array}{l}\text { Government influence } \\
\text { (with control for size) }\end{array}$} \\
\hline & Mean & SD & Mean & SD \\
\hline Greenfield & 2,76 & 1,24 & $-0,06$ & 1,29 \\
\hline Joint Venture & 2,92 & 1,25 & 0,00 & 1,22 \\
\hline Acquisition & 3,05 & 1,24 & 0,03 & 1,19 \\
\hline Partial Acquisition & 3,34 & $\mathbf{1 , 0 7}$ & 0,14 & 1,04 \\
\hline $\mathrm{F}$ & \multirow{2}{*}{\multicolumn{2}{|c|}{$\begin{array}{l}3,78^{\star \star} \\
0,150\end{array}$}} & \multirow{2}{*}{\multicolumn{2}{|c|}{$\begin{array}{c}0,33 \\
0,051\end{array}$}} \\
\hline Eta & & & & \\
\hline
\end{tabular}

Notes: See Table 2.

Table 4 Human resource development and resources access from foreign parent

\begin{tabular}{lcccc}
\hline Entry Mode & $\begin{array}{c}\text { Human resource development } \\
\text { (with control for size) }\end{array}$ & $\begin{array}{c}\text { Access to resources from the parent } \\
\text { (with control for size) }\end{array}$ \\
\hline & Mean & SD & Mean & SD \\
Greenfield & 0,16 & 1,02 & 0,14 & 1,01 \\
Joint Venture & $-0,08$ & 0,91 & $-0,20$ & 1,08 \\
Acquisition & $-0,06$ & 1,01 & 0,01 & 0,80 \\
Partial Acquisition & $\mathbf{- 0 , 3 6}$ & $\mathbf{1 , 1 1}$ & $\mathbf{- 0 , 1 2}$ & $\mathbf{1 , 0 1}$ \\
\hline F & \multicolumn{3}{c}{$3,425^{* *}$} & \multicolumn{3}{c}{$0,287^{*}$} \\
Eta & 0,164 & & 0,135 \\
\hline
\end{tabular}

Notes: See Table 2.

Table 5 Employment effects by entry mode

\begin{tabular}{lcccccc}
\hline Entry Mode & \multicolumn{2}{c}{$\begin{array}{c}\text { Change in employment } \\
\text { per year }\end{array}$} & \multicolumn{2}{c}{$\begin{array}{c}\text { Change in employment per } \\
\text { year (with control for size) }\end{array}$} & \multicolumn{2}{c}{$\begin{array}{c}\text { Absolute change in employment } \\
\text { per year (with control for size) }\end{array}$} \\
\hline & Mean & SD & Mean & SD & Mean & SD \\
Greenfield & 18,34 & 65,70 & $-1,05$ & 70,54 & 2,59 & 61,23 \\
Joint Venture & 6,90 & 18,60 & $-10,05$ & 23,52 & 0,97 & 122,24 \\
Acquisition & $-2,23$ & 154,64 & $-1,09$ & 136,08 & $-9,89$ & 17,34 \\
Partial & $\mathbf{- 1 7 1 , 8 0}$ & $\mathbf{6 3 4 , 6 7}$ & $\mathbf{2 9 , 3 5}$ & $\mathbf{2 9 6 , 6 7}$ & $\mathbf{9 , 3 8}$ & $\mathbf{2 6 2 , 1 9}$ \\
acquisition & & & & & & \multicolumn{2}{c}{0,345} \\
\hline F & \multicolumn{2}{c}{$8,025^{* * *}$} & \multicolumn{2}{c}{0,915} & \multicolumn{2}{c}{0,053} \\
Eta & 0,248 & \multicolumn{2}{c}{0,086} & \\
\hline
\end{tabular}

Notes: See Table 2. 
Table 6 Mean, Standard Deviation and Correlation Matrix

\begin{tabular}{|c|c|c|c|c|c|c|c|c|c|c|}
\hline & & Mean & SD & 1 & 2 & 3 & 4 & 5 & 6 & 7 \\
\hline 1 & Subsidiary Size & 374,63 & 2284,13 & 1 & & & & & & \\
\hline 2 & Ln(subsidiary size) & 3,37 & 1,81 & $0,48 * *$ & 1 & & & & & \\
\hline 3 & Change in employment & $-9,70$ & 231,14 & $-0,84 * *$ & $-0,34 * *$ & 1 & & & & \\
\hline 4 & $\begin{array}{l}\text { Absolute change in } \\
\text { employment }\end{array}$ & 45,96 & 226,72 & $0,87 * *$ & $0,46^{* *}$ & $-0,79 * *$ & 1 & & & \\
\hline 5 & Government influence & 2,94 & 1,24 & 0,08 & $0,17 * *$ & $-0,08$ & $0,14^{* *}$ & 1 & & \\
\hline 6 & $\begin{array}{l}\text { Resource transfer (principal } \\
\text { component) }\end{array}$ & 0,00 & 1,00 & $-0,05$ & $-0,03$ & $0,11^{*}$ & $-0,03$ & 0,02 & 1 & \\
\hline 7 & $\begin{array}{l}\text { Human resource development } \\
\text { (principal component) }\end{array}$ & 0,00 & 1,00 & 0,05 & $0,12^{*}$ & 0,05 & 0,07 & $0,11^{*}$ & $0,39 * *$ & 1 \\
\hline
\end{tabular}

Notes: Poland, Lithuania and Hungary only, levels of significance: $\mathrm{P}<0.01 * *, \mathrm{P}<0.05 *$.

\section{Appendix: Selected items from the CEE survey instrument}

\section{Government influence}

Single item measure on the following statement (scale: $1=$ agree not at all, $5=$ fully agree)

"In our industry, it is important to maintain close personal contact with key officials at the national level”

\section{Availability of resources}

Three item measure on the following questions (scale: $1=$ not at all, $5=$ to a large extent) "Your firm can readily obtain financial resources from the parent firm to finance its expansion" "Your firm can readily obtain financial resources from the parent firm to finance its expansion"

"Your firm can readily obtain technological resources from the parent firm"

\section{Human resources}

Three item measure on the following questions with respect to the last three years (scale: $1=$ not at all, 5 = to a large extent)

"The firm has invested in training and education of its full-time employees"

"There are formal training programs to teach new hires the skills needed to perform their jobs"

"Formal performance appraisals are used to facilitate promotion decisions or to develop employees" 